\title{
Towards a carbon budget of the diazotrophic cyanobacterium Crocosphaera: effect of irradiance
}

\author{
Sophie Rabouille ${ }^{1, *}$, Georges Semedo Cabral ${ }^{1,2}$, Maria Luiza Pedrotti ${ }^{1}$ \\ ${ }^{1}$ Sorbonne Universités, UPMC Univ Paris 06, CNRS, UMR7093, Laboratoire d'Océanographie de Villefranche, \\ 181 Chemin du Lazaret, 06230 Villefranche-sur-mer, France \\ ${ }^{2}$ Present address: Université de Moncton, 18 rue Antonine-Maillet, Moncton (NB) E1A 3E9, Canada
}

\begin{abstract}
We examined changes in carbon fluxes in the marine unicellular diazotrophic cyanobacterium (UCYN) Crocosphaera watsonii in response to irradiance. We estimated changes in the total organic carbon and nitrogen contents, incorporation of carbon into reserves, and exudation processes of extracellular exopolymeric substances (EPS), as well as in the formation of transparent exopolymeric particles (TEP). Variability of cellular carbon pools and extracellular EPS and TEP under conditions of different irradiance and the significance of carbon release in the environment is discussed. Our results show a relationship between growth rate, metabolic processes of carbon incorporation in cells, exudation and irradiance. When growth is light-limited, both carbon production and exudation increase with light. No inhibition occurs at growth-saturating irradiances and half of the total particulate organic carbon is then found as intracellular carbohydrates. While the overall growth becomes light saturated, carbon fixation is further stimulated by higher irradiances, leading to an increased EPS exudation. We found that EPS exudation in C. watsonii is not only a way for cells to release excess carbon, but also occurs when growth is light-limited, even at the lowest irradiance tested. The formation of TEP increases with irradiance, with TEPcarbon amounting to up to $30 \%$ of the total particulate organic carbon. Our data will help to quantify the role of unicellular diazotrophs in the export of both carbon and nitrogen through and below the euphotic zone in the marine environment.
\end{abstract}

KEY WORDS: Carbon cycle $\cdot$ Exudation $\cdot \mathrm{UCYN} \cdot \mathrm{EPS} \cdot \mathrm{TEP} \cdot$ Primary production

\section{INTRODUCTION}

In the open ocean, organic matter originates from the fixation of atmospheric carbon by photoautotrophic organisms. While the elemental composition of bulk organic material is very consistent in the world's oceans, with molar proportions of $\mathrm{C}: \mathrm{N}: \mathrm{P}=$ 106:16:1 (Redfield 1934, Redfield et al. 1963), there is evidence for anomalous surface dissolved inorganic carbon (DIC) drawdown, exceeding the amounts predicted from nitrate availability and the Redfield C:N ratio (Sambrotto et al. 1993). This apparent overconsumption of DIC in regard to nitrogen in phytoplankton cells suggests that organic

${ }^{*}$ Corresponding author: srabouille@obs-vlfr.fr matter produced during photosynthesis does not combine carbon and nitrogen in Redfield proportions. While the overall biomass production is limited by nitrogen availability, photo-assimilation of inorganic carbon may persist. The exudation of surplus carbon through the production of extracellular exopolymeric substances (EPS) such as dissolved organic material (DOM) and transparent exopolymeric particles (TEP) (Mari et al. 2001) may validate and partly counterbalance the hypothesis of DIC overconsumption.

TEP are one type of EPS that form abiotically from acidic polysaccharides released as dissolved and colloidal matter from phytoplankton and bacteria (Zhou

(C) The authors 2017. Open Access under Creative Commons by Attribution Licence. Use, distribution and reproduction are unrestricted. Authors and original publication must be credited. 
et al. 1998, Passow 2000, 2002a). EPS and TEP participate in bloom formation (Passow et al. 1994) and actively take part in the carbon cycle and biogeochemistry in diverse aquatic systems (Alldredge et al. 1993, Passow et al. 2001, Wotton 2004, Bhaskar \& Bhosle 2005). However, the DIC overconsumption hypothesis mentioned above was initially formulated based on $\mathrm{NO}_{3}{ }^{-}$consumption data. With the recent discovery of new open-ocean and coastal, unicellular diazotrophic cyanobacteria (UCYN) (Zehr et al. 2001, Montoya et al. 2004, Moisander et al. 2010), additional nitrogen sources for phytoplanktonic growth were found that also participate in the consumption of surface DIC. Diazotrophic cyanobacteria thrive over a wide range of latitudes in the oceans (Stal 2009, Moisander et al. 2010, Monteiro et al. 2010), where they contribute to primary production. Owing to their ability to fix $\mathrm{N}_{2}$, they play a critical biogeochemical role in nitrogen-depleted oceans, typically in (sub)tropical regions, where they can represent a significant fraction of the plankton biomass (Church et al. 2005). Although the reported contribution of diazotrophs to primary production in these areas is often highly variable, the literature points to a substantial share of the world's ocean's primary production supported by nitrogen fixation (Letelier \& Karl 1996, Karl et al. 1997, Carpenter et al. 2004). Diazotrophs would thus represent an important trophic link in sustaining the biological pump in oligotrophic oceans.

Diazotrophic organisms also produce EPS and TEP (Webb et al. 2009; Dron et al. 2012a), which represent a carbon loss for cells, but how important is this process, in regard to the maintenance of cell growth? In non-diazotrophic primary producers, nitrogen limitation can enhance TEP production (Mari et al. 2001), although nitrogen limitation is not a prerequisite for carbon exudation since TEP production also occurs in non-limiting conditions of nitrogen (Claquin et al. 2008, Pedrotti et al. 2010). The aim of the present work was to describe carbon fluxes in Crocosphaera watsonii, an open-ocean UCYN. Biomass production rates and growth were monitored in duplicate batch cultures grown at a range of light intensities. In order to assess the exudation potential of cells, we tested whether different irradiances resulted in changes in the amount of carbon stored in cells and exuded. The respective cellular carbon pools (including storage carbohydrates and structural carbohydrates, such as sugars contained in glycolipids) as well as extracellular EPS and TEP were compared in regard to the corresponding light treatment. The importance of carbon release into the environment is discussed.

\section{MATERIALS AND METHODS}

\section{Experimental setup}

Monocultures of Crocosphaera watsonii strain WH8501 (Waterbury et al. 1988, Waterbury \& Rippka 1989) were grown in acid-cleaned boro-silicate Erlenmeyer flasks. A teflon tube closed with a clamp was used to ensure aseptic sampling during the experiment. YBCII culture medium (Chen et al. 1996) was prepared from aged Mediterranean Sea surface water collected at the permanent 'Point B' station $\left(43^{\circ} 41^{\prime} 10^{\prime \prime} \mathrm{N}, 7^{\circ} 19^{\prime} 00^{\prime \prime} \mathrm{E}\right)$, filtered through $1 \mu \mathrm{m}$ Millipore Polygard filters and stored in the dark at room temperature for $1 \mathrm{mo}$. Before use, the seawater was filtered (0.1 $\mu \mathrm{m}$ Millipore Polygard filters) and diluted with Milli-Q water up to a final salinity of 35.00 PSU. After sterile addition of dissolved macro- and micronutrients, the medium was transferred to each experimental flask.

The seed culture used for these experiments was kept in a growth chamber at a constant temperature of $27^{\circ} \mathrm{C}$ and exposed to a $12 \mathrm{~h}$ light:12 $\mathrm{h}$ dark regime at approximately $120 \mu \mathrm{mol}$ photons $\mathrm{m}^{-2} \mathrm{~s}^{-1}$. After inoculation, all cultures were placed in the same growth chamber and were manually and gently swirled twice a day for a few minutes, which was enough to stimulate gas exchanges, prevent wall growth and reach efficient growth rates. Cultures were non-axenic but SYBR-Green-stained samples visualized by flow cytometry pointed to a very low contamination level. As reported in Dron et al. (2012b), bacteria were approximately $0.7 \mu \mathrm{m}$ in diameter and accounted for $0.5 \%$ of the total cell abundance, which corresponded to approximately $0.4 \%$ of the total carbon and nitrogen in the cultures. Cultures were exposed to 12 different irradiances ranging from 20 to $500 \mu \mathrm{mol}$ photons $\mathrm{m}^{-2} \mathrm{~s}^{-1}$ applied on one side only to generate a light gradient within the chamber. Irradiance in the chamber was provided by fluorescent tubes (Sanyo FL40SS W/37) and followed a $12 \mathrm{~h}$ light:12 h dark cycle. Flasks were positioned in such a way that (1) no self-shading occurred between the flasks and (2) duplicates received the same incident irradiance. The different levels of irradiance were regularly measured using a US-SQS/LI (WALZ) quantum sensor. A neutral density filter was used to cover a few cultures in order to increase the range of the investigated light gradient.

Flasks were inoculated with exponentially growing culture; the initial concentration in each flask was $9.2 \times 10^{4}$ cells $\mathrm{ml}^{-1}$. 
One set of 10 flasks (5 duplicate cultures) containing $500 \mathrm{ml}$ culture was used for the biochemical analyses and the growth rate measurements described below. Another set of 7 flasks containing $250 \mathrm{ml}$ culture was only sampled for additional growth rate estimations. The experiment was limited to duplicate cultures to prevent self-shading and ensure a constant incident light intensity throughout the experiment. Once growing exponentially, cultures were sampled for 3 consecutive days for identification of the different pools detailed below. Given the significant changes in physiological parameters such as cell size, carbon and nitrogen content that occur in cells of C. watsonii at the hourly scale, samples in each culture were taken in the late light phase, at the same time every day to prevent any bias that would be due to possible diel fluctuations within each culture. Cultures were initiated at low biomass concentration, and the cell density was still low enough at the time of sampling to prevent light limitation.

\section{Cell abundance and particulate organic carbon (POC) and nitrogen (PON)}

Cell abundance and average cell volume were monitored on a daily basis, using a Coulter Counter (Beckman, Multisizer 3). Cell size was estimated as equivalent spherical diameter and used to calculate the cell biovolume. Growth rates, estimated from cell counts, did not show any significant deviations during the sampling period, indicating that cells remained in a similar physiological state over the 3-d monitoring of cellular contents.

The total POC and PON were determined with a CHN analyzer (Perkin Elmer, 2400-II). Samples (5.8 ml) were filtered onto precombusted $\left(4 \mathrm{~h}\right.$ at $\left.450^{\circ} \mathrm{C}\right) \mathrm{GF} / \mathrm{F}$ filters (Whatman) and dried at $60^{\circ} \mathrm{C}$ before analysis. Precombusted, empty filters were used as tare. Carbon and nitrogen contents per cell were estimated using the cell abundance at the time of sampling.

\section{Total cellular carbohydrate and cellular carbohydrate pools}

Samples for carbohydrate analyses were taken in the late light phase in order to determine the carbon content when it is highest. The different intracellular carbohydrate pools and soluble extracellular EPS (SEPS) were analyzed according to Dubois et al. (1956) using glucose as a standard. The concentration of EPS in the fresh culture medium was also measured and subtracted from the results. All fractions obtained were quantified separately and at once, using a dedicated standard curve, to avoid any measurement bias. Immediately before analysis of each fraction, a new standard curve was determined using a range of 9 standard glucose solutions from 0 to $200 \mathrm{mg} \mathrm{l}^{-1}$, prepared freshly and in triplicate from a $5 \mathrm{~g} \mathrm{l}^{-1}$ stock solution. The linear relationship obtained in the standard curve $\left(\mathrm{R}^{2}=0.99\right)$ was used to convert absorbance values into mg equivalents of glucose per sample. Production rates were then estimated from the 3 consecutive samples (48 h span) using the average biomass concentration during that period to account for possible changes in cell concentration during the sampling period.

Duplicate samples of $5.8 \mathrm{ml}$ culture were taken twice, for determination of the total cellular carbohydrate on the one hand, and of the different cellular carbohydrate pools on the other hand according to Dubois et al. (1956). The latter fraction was obtained following the protocol proposed by Dron et al. (2012a). Two analytical replicates were also performed during the analyses. All samples were filtered through $1 \mu \mathrm{m}$ polycarbonate filters at gentle vacuum $(<150 \mathrm{~mm}$ of $\mathrm{Hg}$ ) so as not to disrupt cells, and filters were placed in $15 \mathrm{ml}$ Falcon ${ }^{\circledR}$ tubes (Corning $\left.{ }^{\circledR}\right)$ and stored at $-80^{\circ} \mathrm{C}$ until analysis. Total cellular carbohydrate and all cellular carbohydrate fractions were then converted into fmol C cell ${ }^{-1}$ according to Pakulski \& Benner (1992), using the cell volume measured at the time of sampling and considering that carbon represents $40 \%$ of the mass of glucose.

\section{Extracellular pools: soluble EPS and TEP}

S-EPS comprise an extracellular carbohydrate fraction dissolved in water and can be isolated from particulate material by gentle vacuum filtration $(<150 \mathrm{~mm}$ of $\mathrm{Hg}$ ) of the culture through a $0.2 \mu \mathrm{m}$ polycarbonate filter (Benner et al. 1992, Underwood et al. 1995). The filtrate was collected in a $15 \mathrm{ml}$ Falcon ${ }^{\circledR}$ tube and stored at $-80^{\circ} \mathrm{C}$ until analysis according to Dubois et al. (1956).

TEP are acidic, exo-polysaccharides; this fraction was quantified by spectrophotometry according to the dye-binding assay (Passow \& Alldredge 1995) using Alcian Blue as a stain. Duplicate samples of $11.6 \mathrm{ml}$ were filtered through a $0.4 \mu \mathrm{m}$ polycarbonate filter at low vacuum pressure to preserve cells, and the filter was stored in a $15 \mathrm{ml}$ Falcon ${ }^{\circledR}$ tube at $-20^{\circ} \mathrm{C}$ until analysis. Two analytical replicates were also performed during the analyses. TEP values were 
expressed as xanthan gum (XG) weight equivalent $\left(\mu \mathrm{g} \mathrm{XG} \mathrm{^{-1 }}\right.$ ) calculated by means of a calibration curve using 12 concentrations of xanthan gum (in triplicate) according to Claquin et al. (2008). Linear regressions were fitted to the calibration data with a coefficient of determination of $R^{2}=0.98$. The carbon content of TEP (TEP-C) was estimated from colorimetric determinations $\left(\mathrm{TEP}_{\text {color }}\right)$ as:

$$
\text { TEP-C }=0.75 \times \mathrm{TEP}_{\text {color }}
$$

where TEP-C is given in $\mu \mathrm{g} \mathrm{l}^{-1}$ and TEP color in $\mu \mathrm{g} \mathrm{XG}$ $\mathrm{l}^{-1}$ (Engel \& Passow 2001).

A control measurement was performed in the culture medium prior to inoculation to confirm the absence of EPS in the medium.

\section{Statistical analysis}

Average concentrations are provided with their related standard error of the mean (SEM). To determine whether the measured POC, PON and carbon pools show significant differences between the light treatments, an ANOVA with one classification criterion was performed, followed by a post hoc Tukey's HSD test. Data normality of the different data sets was verified using the Rankit test (Bliss et al. 1956). The homogeneity of variance was confirmed using Levene's test (Levene 1960).

\section{RESULTS}

\section{Growth dynamics}

All cultures showed an exponential growth with good reproducibility between replicates. The exponential growth rates $(\mu)$ obtained in the different treatments revealed a saturation relationship with irradiance (Fig. 1). An increase in $\mu$ was observed in all cultures up to $150 \mu \mathrm{mol}$ photons $\mathrm{m}^{-2} \mathrm{~s}^{-1}$, before tapering off around $0.5 \mathrm{~d}^{-1}$ at higher irradiances. Fitting the Monod (1942) model to these data (Fig. 1) predicted a theoretical, maximum growth rate $\mu_{\max }=0.6 \mathrm{~d}^{-1}$ and a half-saturation constant for light utilization $K_{\mathrm{I}}=98.8 \mu \mathrm{mol}$ photons $\mathrm{m}^{-2} \mathrm{~s}^{-1}$, with a determination coefficient $\mathrm{R}^{2}=0.95$.

Cultures processed for biomass quantifications were grown at irradiances from
50 to $350 \mu \mathrm{mol}$ photons $\mathrm{m}^{-2} \mathrm{~s}^{-1}$. Due to the large number of samples taken for biochemical analyses, not all cultures could be sampled during the exact few days of their respective highest growth rate. In particular, growth had reached a plateau when the set of cultures exposed to the highest irradiance $(350 \mu \mathrm{mol}$ photons $\mathrm{m}^{-2} \mathrm{~s}^{-1}$ ) was sampled. Culture replicates showed consistent behavior and results for each light treatment are presented as average values between replicates. When exposed to higher light intensity, cells became larger. The average cell biovolume recorded in each culture over the 3-d sampling period increased with irradiance from $10.71 \mu^{3}$ in cultures grown at $50 \mu \mathrm{mol}$ photons $\mathrm{m}^{-2} \mathrm{~s}^{-1}$ to $13.25 \mathrm{~mm}^{3}$ in those grown at $350 \mu \mathrm{mol}$ photons $\mathrm{m}^{-2} \mathrm{~s}^{-1}$, representing a $24 \%$ biovolume gain (Fig. 1).

\section{Total $\mathbf{C}$ and $\mathbf{N}$ contents and cellular carbohydrates pools}

When expressed per cell, there was a significant linear increase in POC and PON along the range of irradiance up to $275 \mu \mathrm{mol}$ photons $\mathrm{m}^{-2} \mathrm{~s}^{-1}$ (Fig. 2). POC increased from $264.7 \pm 13.8$ (SEM) fmol C cell ${ }^{-1}$ at $50 \mu \mathrm{mol}$ photons $\mathrm{m}^{-2} \mathrm{~s}^{-1}$ to $443.6 \pm 12.8 \mathrm{fmol} \mathrm{C}^{\mathrm{C}} \mathrm{cell}^{-1}$

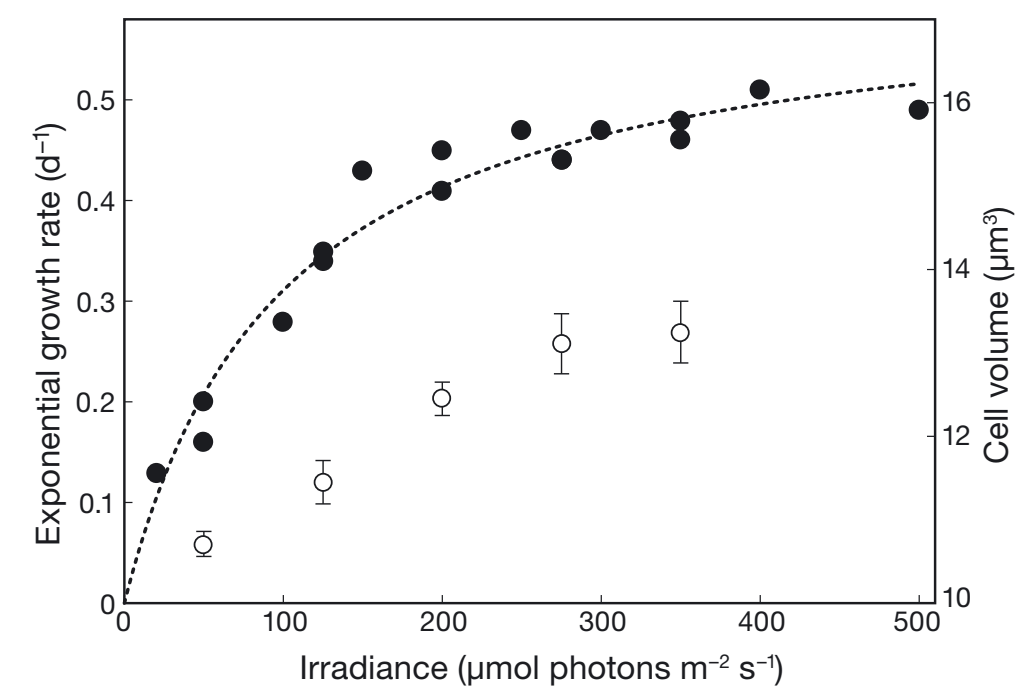

Fig. 1. Exponential growth rate $\mu\left(\mathrm{d}^{-1}\right)$ observed in cultures of Crocosphaera watsonii as a function of irradiance (closed circles; left axis) and average $\left( \pm\right.$ SEM) cell biovolume (open circles; $\mu \mathrm{m}^{3}$, right axis). Note the scale on the secondary $y$-axis. A Monod relationship (dotted line) was fitted to the growth rate data, which predicts a maximum growth rate $\mu_{\max }$ of $0.6 \mathrm{~d}^{-1}$ and a half saturation constant $K_{\mathrm{I}}=98.8 \mu \mathrm{mol}$ photons $\mathrm{m}^{-2} \mathrm{~s}^{-1}$. The quality of the fit was assessed by estimating the determination coefficient of this non-linear relationship: $\mathrm{R}^{2}=1-\left(\mathrm{SS}_{\mathrm{e}} / \mathrm{SS}_{\mathrm{t}}\right)$, where $\mathrm{SS}_{\mathrm{e}}$ is the sum of the square differences between data $y$ and model estimations $\hat{y}: \mathrm{SS}_{e}=\sum(y-\hat{y})^{2}$ and $\mathrm{SS}_{\mathrm{t}}$ is the sum of the squares of the distances between data $y$ and their average $\bar{y}: \mathrm{SS}_{t}=\Sigma(y-\bar{y})^{2}$ 


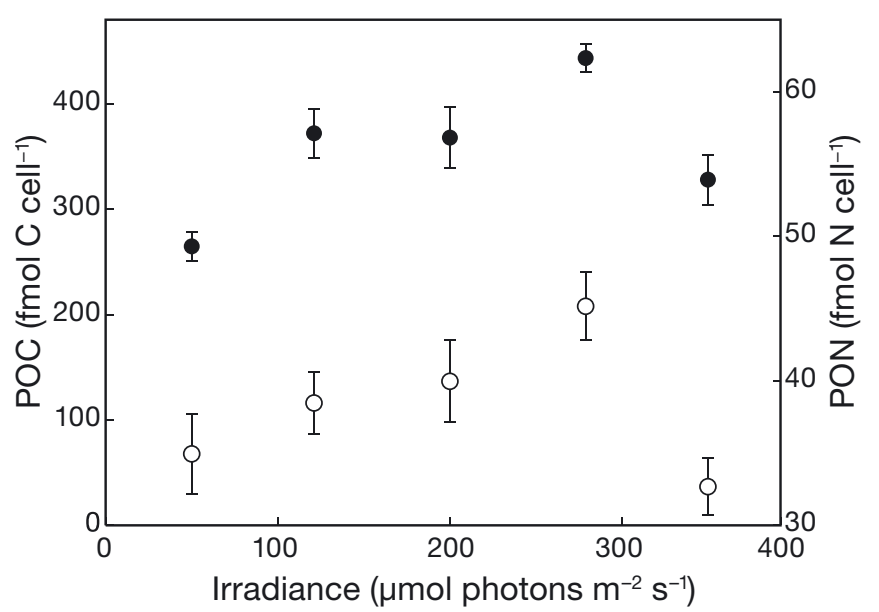

Fig. 2. Average total particulate organic carbon (POC; closed circles; fmol C cell-1 ${ }^{-1}$ left axis) and nitrogen (PON; open circles; fmol $\mathrm{N} \mathrm{cell}^{-1}$, right axis) per cell in cultures exposed to increasing irradiances. Each data point is the average of 6 time points (samples taken for 3 consecutive days in duplicate cultures). Error bars are $\pm \operatorname{SEM}(n=6)$. A linear regression is observed over the first 4 irradiances for both POC and PON, whose respective determination coefficients $\left(R^{2}\right)$ are 0.87 and 0.96
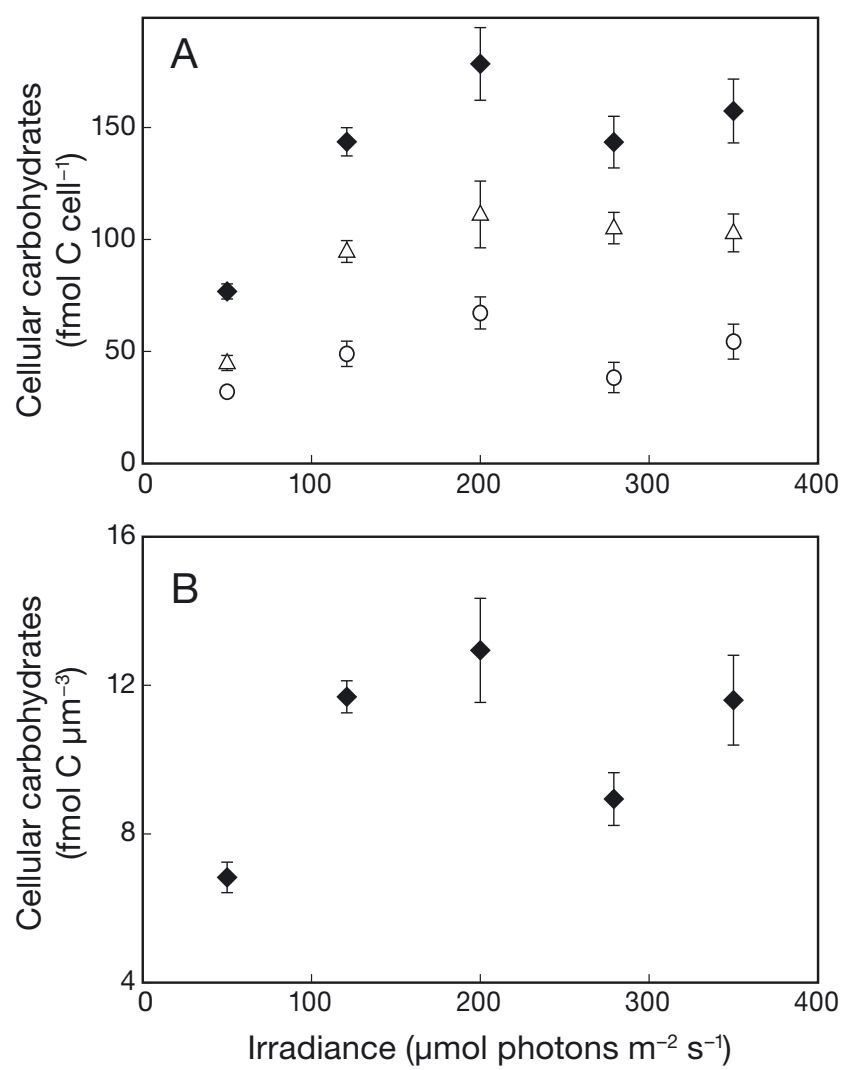

Fig. 3. Average reserve (open circles), structure (open triangles) and total (reserve + structure; diamonds) carbohydrate content in cultures grown at different light intensities, expressed (A) per cell (fmol C cell-1) and (B) per biovolume $\left(\mathrm{fmol} \mathrm{C} \mu \mathrm{m}^{-3}\right)$. Error bars are $\pm \operatorname{SEM}(\mathrm{n}=6)$ at $275 \mu \mathrm{mol}$ photons $\mathrm{m}^{-2} \mathrm{~s}^{-1}\left(\mathrm{R}^{2}=0.87\right.$; $\left.\mathrm{p}<0.01\right)$, while PON evolved from $34.9 \pm 2.8$ to $45.2 \pm 2.3 \mathrm{fmol} \mathrm{N}$ cell $^{-1}$ $\left(\mathrm{R}^{2}=0.95 ; \mathrm{p}<0.01\right)$. Cultures grown at $350 \mu \mathrm{mol}$ photons $\mathrm{m}^{-2} \mathrm{~s}^{-1}$ were an exception and stand out from the increasing trend, with a smaller cell volume and cellular content.

The discrimination and quantification of internal carbon pools, carried out in parallel, indicate a carbohydrate buildup in cells with increased irradiances up to $200 \mu \mathrm{mol}$ photons $\mathrm{m}^{-2} \mathrm{~s}^{-1}$. Fig. 3A represents cellular contents in structure, reserve and total (i.e. structural + reserve) carbohydrates; both reserve $\left(\mathrm{R}^{2}=0.99\right)$ and structure $\left(\mathrm{R}^{2}=0.92\right)$ pools showed a saturation relationship with irradiance. Reserve carbohydrates doubled from an average of $32 \mathrm{fmol} \mathrm{C}^{\mathrm{C}} \mathrm{fl}^{-1}$ in cultures exposed to $50 \mu \mathrm{mol}$ photons $\mathrm{m}^{-2} \mathrm{~s}^{-1}$, to $67 \mathrm{fmol} \mathrm{C} \mathrm{cell}^{-1}$ at $200 \mu \mathrm{mol}$ photons $\mathrm{m}^{-2} \mathrm{~s}^{-1}$. Structural carbohydrates also showed a near 2-fold increase, from $17 \mathrm{fmol} \mathrm{C}$ cell $^{-1}$ to $31 \mathrm{fmol} \mathrm{C}$ cell $^{-1}$ in the same range of irradiances (Fig. 3A). Accumulation of cellular reserve and structure carbohydrates saturated above $200 \mu \mathrm{mol}$ photons $\mathrm{m}^{-2} \mathrm{~s}^{-1}$ and cultures even showed sub-maximal contents. Total carbon (POC) expressed per biovolume did not change significantly with irradiance. On the contrary, carbohydrate contents, whether expressed per biovolume or per carbon unit, did increase with irradiance up to $200 \mu \mathrm{mol}$ photons $\mathrm{m}^{-2} \mathrm{~s}^{-1}(\mathrm{p}<0.01)$, pointing to a reserve accumulation in cells. This increase in carbohydrate storage saturated beyond $200 \mu \mathrm{mol}$ photons $\mathrm{m}^{-2} \mathrm{~s}^{-1}$ (Fig. 3B). These results indicate that carbon accumulation is not to be related to the increase in cell size only; at higher light levels there is an increase in total carbon with larger proportions of POC found as carbohydrates: $50 \%$ at $200 \mu \mathrm{mol}$ photons $\mathrm{m}^{-2} \mathrm{~s}^{-1}$ versus $29 \%$ at $50 \mu \mathrm{mol}$ photons $\mathrm{m}^{-2} \mathrm{~s}^{-1}$.

\section{EPS and TEP production rates}

Production rates can be reasonably estimated from 2 closely related time points, between which little change in biomass can be assumed. In the present study, the time interval between 2 samples is $1 \mathrm{~d}$ and production rates were calculated as follows:

$$
\text { Production rate }=\left(\mathrm{Pool}_{t+\delta t}-\mathrm{Pool}_{t}\right) /(\bar{B} \times \delta t)
$$

where $\mathrm{Pool}_{t+\delta t}-\mathrm{Pool}_{t}$ is the concentration of the element formed or consumed during the time interval $\delta t$, expressed as fmol $\mathrm{Cl}^{-1}$, and $\bar{B}$ is the average biomass concentration during the same time interval: $\bar{B}=$ $0.5 \times\left(B_{t+\delta t}+B_{t}\right)$, expressed as cells $\mathrm{l}^{-1}$.

At the time of sampling, the highest absolute EPS concentration expressed relative to cell abundance 


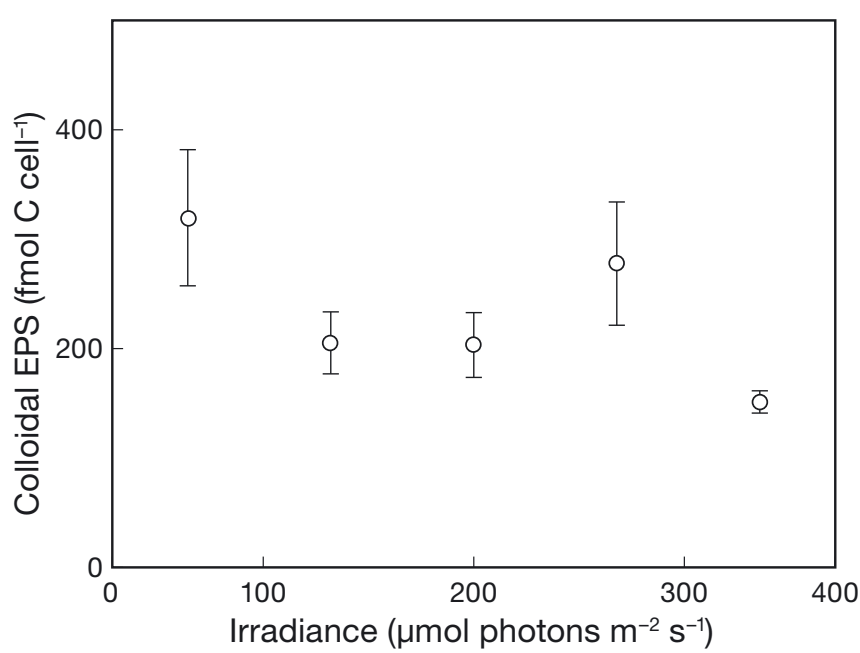

Fig. 4. Average colloidal extracellular exopolymeric substance (EPS) concentration (fmol C cell ${ }^{-1}$ ) in cultures exposed to different light intensities, and expressed relative to cell abundance. Error bars are $\pm \operatorname{SEM}(\mathrm{n}=6)$

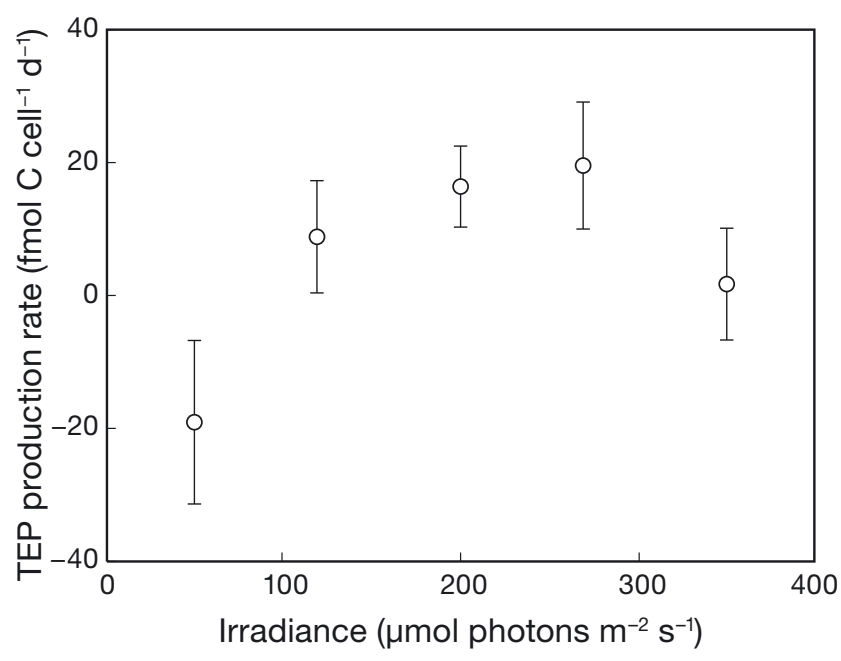

Fig. 5. Average net transparent exopolymeric particle (TEP) production rate in duplicate cultures of $C$. watsonii exposed to different irradiances. Error bars are $\pm \operatorname{SEM}(n=6)$.

(319.6 \pm 62.2 fmol $C$ cell $\left.^{-1}\right)$ was observed in cultures exposed to the lowest light intensity, and the lowest EPS concentration $(151.2 \pm 10.2 \mathrm{fmol} \mathrm{C}$ cell $^{-1}$ ) was observed in cultures exposed to the highest light intensity. The cultures grown at intermediate irradiances showed an overall decreasing trend in EPS concentration (Fig. 4). Average EPS production rates, calculated over the $3 \mathrm{~d}$ of sampling, yielded mostly negative values, indicative of a disappearance of EPS rather than a production. Rates ranged from $-25 \mathrm{fmol} \mathrm{C}$ cell ${ }^{-1} \mathrm{~d}^{-1}$ at $50 \mu \mathrm{mol}$ photons $\mathrm{m}^{-2} \mathrm{~s}^{-1}$ to $4.22 \mathrm{fmol} \mathrm{C} \mathrm{Cell}^{-1} \mathrm{~d}^{-1}$ at $350 \mu \mathrm{mol}$ photons $\mathrm{m}^{-2} \mathrm{~s}^{-1}$.
Although an abiotic process, TEP formation is affected by cell exudation and so is likely to depend on cell density. Therefore, we normalized the concentration of TEP relative to cell abundance, which also allows for comparison with other carbon pools. Importantly, normalization by cell abundance did not affect the dynamics described in the 'Discussion', which remained true when considering absolute concentrations per volume (mg C $\mathrm{l}^{-1}$ for instance). TEP were detected in all cultures and their concentration varied from $77 \mathrm{fmol} \mathrm{C}$ cell $^{-1}$ at $50 \mu \mathrm{mol}$ photons $\mathrm{m}^{-2}$ $\mathrm{s}^{-1}$ to $123.5 \mathrm{fmol} \mathrm{C} \mathrm{cell}^{-1}$ at $275 \mu \mathrm{mol}$ photons $\mathrm{m}^{-2} \mathrm{~s}^{-1}$, thus representing a $60 \%$ increase. Accordingly, the net TEP production rate increased with light intensity, although not linearly (Fig. 5). The order of magnitude of this process was similar to that of EPS production, with a maximum rate of $19.5 \pm 9.5 \mathrm{fmol} \mathrm{C}$ cell $^{-1} \mathrm{~d}^{-1}$ at $275 \mu \mathrm{mol}$ photons $\mathrm{m}^{-2} \mathrm{~s}^{-1}$. However, an exception is observed in cultures exposed to $350 \mu \mathrm{mol}$ photons $\mathrm{m}^{-2} \mathrm{~s}^{-1}$, which stand apart from the trend and show a lower production rate.

\section{DISCUSSION}

Among the different lineages of diazotrophs, unicellular cyanobacteria have been given increasing attention in the last 2 decades (Zehr et al. 2000). These include UCYN-B, a group of phototrophic cyanobacteria, whose cultured representatives are strains from the genus Crocosphaera (Zehr et al. 2001), which are widely distributed in the world's (sub)tropical oceans (Church et al. 2005, Hewson et al. 2007, Zehr et al. 2007).

The ecophysiology of Crocosphaera still shows a number of puzzling features. For instance, the cell cycle (Dron et al. 2013) as well as diel cycles of gene expression (Mohr et al. 2010, Shi et al. 2010) tightly control the different metabolic processes, which participate in maintaining a stable elemental stoichiometry at the daily scale (Dron et al. 2012b). But there is evidence for discrepancies between the net metabolic rates, deduced from the net growth rate, and actual activities of carbon and nitrogen acquisition, that seem to largely exceed the metabolic costs for these activities. For instance, gross nitrogen fixation in Crocosphaera watsonii WH8501 would exceed up to 3 -fold the nitrogen requirements for growth under conditions of exponential, balanced growth (Dron et al. 2012b). Such luxury growth dynamics associated with a release of compounds into the environment has also been observed in a number of other phototrophic diazotrophs, such as Cyanothece BG 43511, which ex- 
udes up to $89 \%$ of its recently fixed nitrogen (Agawin et al. 2007), or Trichodesmium, reported to release 50 to $90 \%$ of the fixed nitrogen (Capone et al. 1994, Glibert \& Bronk 1994, Mulholland \& Bernhardt 2005).

Carbon exudation by phytoplanktonic or cyanobacterial cells occurs through the release of EPS, which promotes the formation of TEP. These have been related to the photosynthetic rate (Mague et al. 1980, Claquin et al. 2008) or the growth rate (Waite et al. 1995). While the ability of diazotrophs to exude carbon compounds is documented in the literature (Berman-Frank et al. 2007, Webb et al. 2009, Sohm et al. 2011, Dron et al. 2012a), it is still unclear how significant these fluxes are for the biogeochemistry of their environment. In unicellular strains, such as $C$. watsonii, one could wonder whether the energydemanding diazotrophic growth would permit significant carbon losses. In the following text, we show that it actually does.

\section{Irradiance-growth relationship}

The growth kinetics data reveal a saturation in the growth response to irradiance, accurately fitted using the Monod (1942) model, with a saturation threshold around $200 \mu \mathrm{mol}$ photons $\mathrm{m}^{-2} \mathrm{~s}^{-1}$ (Fig. 1). The absence of any reduced growth rate at the highest irradiances could suggest that none of the light levels applied here were inhibiting. However, a markedly reduced POC and PON content (Fig. 2), as well as a reduced EPS concentration and TEP production (Figs. 4, 5), at the highest irradiance may instead reflect the initiation of photoinhibition. We believe that the absolute threshold value for light saturation observed here is not an unalterable, physiological feature of $C$. watsonii but rather reflects the long-term light-acclimation state of this strain at the time at which this experiment was conducted. This strain features a certain resistance to strong lights (Rabouille \& Claquin 2016). It is likely that, had cultures been pre-acclimated at higher irradiances, the saturation relationship would have remained, but with a threshold possibly shifted towards higher light levels (e.g. see Mortain-Bertrand et al. 1988). In the following subsections, we show that such a saturation relationship also characterizes the different processes of carbon and nitrogen acquisition.

All samples for biochemical analyses were taken in the second half of the light period. As expected, the molar C:N ratios exceeded the Redfield value, indicating that cells were accumulating carbon in all cultures. C:N ranged from 7.45 and 7.72 at the lowest irradiance to 9.87 and 10.21 at the highest irradiance.
This range consistently brackets values previously reported for this strain: when considering the same time window, this ratio varied from 8.5 to 9.5 in continuous cultures of $C$. watsonii grown in similar conditions and exposed to a bell shape, $12 \mathrm{~h}$ light:12 $\mathrm{h}$ dark regime with a maximum of $130 \mu \mathrm{mol}$ photons $\mathrm{m}^{-2} \mathrm{~s}^{-1}$ (Dron et al. 2012b).

\section{Light-limited growth processes}

At increasing sub-saturating irradiances, cells not only grow faster, they are bigger (Fig. 1) and contain more cellular compounds (Fig. 2). POC per cell increased by $68 \%$ between 50 and $275 \mu \mathrm{mol}$ photons $\mathrm{m}^{-2} \mathrm{~s}^{-1}$. This trend is mirrored in the PON cell content, pointing to a light stimulation of nitrogen fixation, but with a lower rate of change ( $29 \%$ increase). As a result, a carbon surplus accumulates in cells, shown by the increase in the $\mathrm{C}: \mathrm{N}$ ratio with irradiance. POC accumulation reflects the dynamics of the cellular carbon pools; when exposed to higher irradiances, cells build up more structural carbon but they also increase their storage reserves (Fig. 3). The proportion of reserve carbohydrates increases from $12.2 \%$ of POC at $50 \mu \mathrm{mol}$ photons $\mathrm{m}^{-2} \mathrm{~s}^{-1}$ to $19 \%$ at $200 \mu \mathrm{mol}$ photons $\mathrm{m}^{-2} \mathrm{~s}^{-1}$. Altogether, cellular carbohydrates then account for $29 \%$ (at $50 \mu \mathrm{mol}$ photons $\mathrm{m}^{-2} \mathrm{~s}^{-1}$ ) to $50 \%$ (at $200 \mu \mathrm{mol}$ photons $\mathrm{m}^{-2} \mathrm{~s}^{-1}$ ) of the total POC in the cultures. The present data assert that the commonly observed, widely fluctuating pools of cellular carbohydrates are a signature in cyanobacteria and an important component of their ecology, whether in diazotrophic strains (Schneegurt et al. 1994, Rabouille et al. 2006, Dron et al. 2012b) or nondiazotrophic strains, such as Microcystis sp. (Rabouille \& Salencon 2005, Rabouille et al. 2005).

The absolute concentration of any element or pool results from processes of production and losses (such as possible degradation, consumption or transformation) that occur between the inoculation and the moment of sampling. At any time, the instantaneous net production rate is directly dependent on the biomass concentration as well as on the growth status of cells. Therefore, for a relevant production rate to be estimated, it is critical to relate the measured compound concentrations to the actual cell abundance responsible for production or loss. Following the stimulation of POC production by light in C. watsonii, one might reasonably expect that carbon exudation increases as well, as already reported for several non-diazotrophic phytoplankton strains (Zlotnik \& Dubinski 1989). The fast transient dynamics of the 
EPS pool, together with the negative values of EPS production rates observed up to $200 \mu$ mol photons $\mathrm{m}^{-2} \mathrm{~s}^{-1}$, point to a net decrease in the EPS fraction, even though the rate of EPS production appears to increase with the irradiance. In parallel, absolute concentrations measured in the cultures indicate that the residual EPS is inversely related to the irradiance level (Fig. 4). These 2 observations suggest that the application of higher light levels triggered increases in EPS production, while their aggregation into TEP (see below) is responsible for an even higher decrease in the concentration of EPS. Overall, results point to fast dynamics of the extracellular carbon pools, whose kinetics prove non-trivial to describe. The actual dynamics of the EPS pool may not be seen at time scales longer than those of metabolic processes. It is also still unclear whether EPS exudation is a continuous process or, on the contrary, whether EPS are actively released only at certain phases of the growth cycle. We wonder, for instance, to what extent the exudation process is correlated with the cell division cycle, with increased exudation following carbon incorporation (a possible consequence of excess carbon incorporation) and/or decreased exudation during the cell division phase (when cells need cellular material to make new daughter cells). Fluorescent probes would probably help to further characterize this phenomenon. Comparison of Figs. 3 and 4 indicates that, although exuded EPS are rapidly removed from the dissolved pool, the remaining EPS concentration in cultures is of the same order of magnitude as the total carbohydrates in cells (and even 4 times more at the lowest irradiance), demonstrating that, in exponentially growing cultures, a significant fraction of carbon incorporated daily through photosynthesis is actually released into the environment. We believe that EPS exudation is much more than just an outlet for excess fixed carbon. The magnitude of EPS exudation, especially at low irradiances, is strong evidence of its constitutive character: carbon release would be part of the growth process, whether it is light limited or light saturated. Nutrients and cell exudates trapped in the EPS matrix (Flemming \& Wingender 2001) remain available to cells in the colony. In the natural environment, such a constantly enriched, extracellular matrix would even constitute a possible attachment surface and substrate for symbiotic consortia to set up.

Despite fluctuating production rates between consecutive days, the averaged TEP production rates showed reproducibility between duplicates, and the data showed evidence of a very clear, positive stimulation of TEP production by increasing irradiances
(Fig. 5). We believe the culture experiment did not introduce artifacts in TEP formation, as a similar relationship between incident irradiance and TEP formation was also reported in natural phytoplankton assemblages (Hong et al. 1997). The formation of TEP per se is an abiotic process; therefore, it is most certainly not directly affected by the ambient light intensity, but instead depends on the amount of dissolved and colloidal material in the medium. Following the observations of Passow (2000), data suggest that the accumulation of EPS in the present cultures concomitantly stimulated the formation of TEP. The present data suggest that the more EPS are exuded, the more they collate into TEP, and the lesser EPS remain (as observed in cultures exposed to higher irradiances). The non-linearity in the relationship between irradiance and TEP production is further caused by the fact that TEP production also relies on turbulence (Klein et al. 2011), as well as on bacterial degradation and grazing (Mari \& Burd 1998, Penna et al. 1999, Kiorbøe 2000, Garcia et al. 2002), although the exact role of these processes in TEP formation in the natural environment may still be debated.

\section{Light-saturated growth processes}

At the highest irradiances investigated, cultures showed a light-saturated growth with no further accumulation of cellular compounds (Fig. 3). Cells most probably reached their maximal average size. Given the saturation trend in the growth response depicted in Fig. 1, we expected the different cellular parameters to reach a plateau in cultures exposed to irradiances above $200 \mu \mathrm{mol}$ photons $\mathrm{m}^{-2} \mathrm{~s}^{-1}$. Yet, at $275 \mu \mathrm{mol}$ photons $\mathrm{m}^{-2} \mathrm{~s}^{-1}$, the cell biovolume, POC and PON kept increasing even though the intracellular carbohydrates pools showed the expected saturation. Considering that GF/F filters can actually collect some TEP (Engel \& Passow 2001) and given the much higher concentration of TEP observed in these cultures, we suspect that the presence of TEP could be the reason for the high POC measured. Importantly, we bring up again some methodological issues that may not have resounded through the literature: Moran et al. (1999) showed that when assessing primary production, the measured ${ }^{14} \mathrm{C}$ incorporation rates vary depending on whether a GF/F or polycarbonate filter is used to collect the biomass. They point to higher carbon incorporation on GF/F filters, which they attribute to the retention of labelled DOC on the filter. Given the risk of DOC adsorption on GF/F filters, we acknowledge that there is scope for improve- 
ment in the present experimental protocol; yet, our protocol rigorously follows methods used in the literature, which was required to make our study comparable with all the data published so far. Our results also remain valid when comparing the magnitude of exudation between treatments, which was the main purpose of the present work.

The POC, PON and carbohydrates contents measured in cultures exposed to $350 \mu \mathrm{mol}$ photons $\mathrm{m}^{-2} \mathrm{~s}^{-1}$ are lower than expected in regard to the saturation relationship. Cells also appear smaller. We believe these measurements are reliable because the analyses, performed on distinct pools in different samples from 2 cultures, show congruent results. Sampling was done in the late growth phase in these cultures, which then showed a reduced growth rate; these actually showed an altered dynamic. In our experiments, we explored the exponential growth capacity and not the behavior of likely pre-senescent cells. Because they are not representative of the exponential growth dynamics expected at this light level, these cultures are not further considered in this study. From a methodological point of view, this observation stresses how much a correct analysis of the growth dynamics in response to environmental conditions is bound to an accurate comprehension of the growth status of cells at the time of sampling.

As cell concentration varies exponentially in time, the inaccuracy of estimated production increases with the time interval. In our study, we followed cell dynamics on a daily basis in our cultures, and pool concentrations were measured over $3 \mathrm{~d}$ to derive 2 consecutive production rates over the period of sampling, with a $24 \mathrm{~h}$ interval. In 2 cultures growing at 0.5 and $0.15 \mathrm{~d}^{-1}$, cells will on average take 1.4 and $4.6 \mathrm{~d}$ to divide, respectively. The estimated production rates will be strongly affected by the occurrence, or not, of cell division within the considered time interval. This fact at least partly explains why our cultures showed fluctuating net EPS production rates from day to day. Bacterial contamination in the cultures could be a partial sink for released EPS, but due to the extremely low contamination observed in our cultures, the related consumption is considered negligible. Importantly, because EPS participate in the formation of TEP, the measured EPS production is a net apparent rate, which does not reflect the actual gross EPS exudation, should EPS collate into TEP at a fast rate.

Wotton (2004) suggested that EPS production was a way for cells to release excess carbon. If EPS exudation was exclusively consequent to an over-accumulation of carbon, then such release should only be observed once cell growth becomes light saturated and cells have reached their maximum storage capacity. Instead, the present results evidence a sustained increase in EPS exudation following a stimulation of photosynthesis by increasing irradiance. When the growth rate is light saturated, then releasing EPS does appear as a way out for excess carbon, which, as discussed by Otero \& Vincenzini (2004), compensates for excess reducing power when carbon and nitrogen metabolism become too unbalanced.

\section{Probable impacts in the natural environment}

We expect the permanent release of EPS and formation of TEP under different light conditions by diazotrophic cells to represent a steady supply to other communities in the natural environment. Such provision of organic molecules will benefit bacteria and the microbial carbon pump. Given the possible mixotrophy in a number of phytoplankton groups, it is likely that blooms of diazotrophs also create conducive conditions for the immediate development of phototrophic communities in oligotrophic areas. Released as dissolved material, EPS may remain as such and be used locally. However, the present data suggest that a significant fraction actually enters the particulate pool when aggregating into TEP, where they add to the export flux.

TEP formation is related to carbon overproduction by cells. TEP are carbon-rich exopolymers, composed of various polysaccharides that can aggregate nitrogen molecules such as amino acids, even though they have a C:N ratio above Redfield (Engel \& Passow 2001). As emphasized by Passow (2002b), the sedimentation of carbon-rich TEP is thought to decouple the cycles of carbon and nitrogen in the marine environment. But in blooms of diazotrophs, the potentially high nitrogen excretion rates would move the TEP composition closer to the Redfield balance. As a consequence, sedimentation processes following the development of blooms of nitrogen fixers can represent an export of both carbon and nitrogen towards deeper layers, if these have not benefitted other communities within the euphotic zone.

\section{CONCLUSIONS}

In line with observations in the eukaryote Emiliania huxleyi (Engel et al. 2004), we found that carbon exudation as EPS in the prokaryote C. watsonii WH8501 is constitutive of growth and increases with the rate of carbon acquisition. While carbon storage 
and cell growth rate saturate at high light with up to $50 \%$ of the POC found as intracellular carbohydrates, both EPS exudation rates and the subsequent formation of TEP further increase with irradiance. Exudation is not an outlet for carbon fixed in excess but instead takes part in the overall growth strategy of this organism. As a consequence, diazotrophic cyanobacteria show a much wider impact on the environment than solely a stimulation of primary production. Their gross activities generate direct fluxes of carbon and nitrogen into their environment, which, when contributing to the dissolved compartment, are excluded from primary production estimates. Our results highlight a significant exudation capacity in C. watsonii, with EPS concentrations amounting to 1 - to 2 -fold the cellular carbohydrates and TEP representing up to $30 \%$ of the biomass standing stock (expressed as carbon), illustrating the impact of these organisms on the carbon cycle in the current upper ocean. We believe that UCYN both stimulate the bacterial pump and exert a non-negligible contribution to export in oligotrophic oceans.

Ackowledgements. This study was supported by the LEFE (Les Enveloppes Fluides de l'Environment; Crococycle project) and ANR (Agence nationale de la recherche; Purple Sun project) funding programs, the Conseil Général des Alpes Maritimes and the Conseil Régional Provence Alpes Côte d'Azur. We thank A. Dron for his comments regarding the protocols. We are very grateful to M.-E. Kerros and A. Talec for their technical support and advice, to P. Nival for his constructive comments on the results, and to J. R. Dolan for reading and commenting on the manuscript. We are also very grateful to the three anonymous referees, who had very constructive comments and helped highlight the overall impact of this work.

\section{LITERATURE CITED}

Agawin NSR, Rabouille S, Veldhuis MJW, Servatius L, Hol S, van Overzee HMJ, Huisman J (2007) Competition and facilitation between unicellular nitrogen-fixing cyanobacteria and non-nitrogen-fixing phytoplankton species. Limnol Oceanogr 52:2233-2248

Alldredge AL, Passow U, Logan BE (1993) The abundance and significance of a class of large, transparent organic particles in the ocean. Deep Sea Res I 40:1131-1140

* Benner R, Pakulski JD, McCarthy M, Hedges JI, Hatcher PG (1992) Bulk chemical characteristics of dissolved organic matter in the ocean. Science 255:1561-1564

Berman-Frank I, Rosenberg G, Levitan O, Haramaty L, Mari $\mathrm{X}$ (2007) Coupling between autocatalytic cell death and transparent exopolymeric particle production in the marine cyanobacterium Trichodesmium. Environ Microbiol 9:1415-1422

Bhaskar PV, Bhosle NB (2005) Microbial extracellular polymeric substances in marine biogeochemical processes. Curr Sci 88:45-53
Bliss CI, Greenwood ML, White ES (1956) A Rankit analysis of paired comparisons for measuring the effect of sprays on flavor. Biometrics 12:381-403

Capone DG, Ferrier MD, Carpenter EJ (1994) Amino-acid cycling in colonies of the planktonic marine cyanobacterium Trichodesmium thiebautii. Appl Environ Microbiol 60:3989-3995

Carpenter EJ, Subramaniam A, Capone DG (2004) Biomass and primary productivity of the cyanobacterium Trichodesmium spp. in the tropical N Atlantic Ocean. Deep Sea Res I 51:173-203

* Chen YB, Zehr JP, Mellon M (1996) Growth and nitrogen fixation of the diazotrophic filamentous non heterocystous cyanobacterium Trichodesmium sp IMS 101 in defined media: evidence for a circadian rhythm. J Phycol 32:916-923

* Church MJ, Jenkins BD, Karl DM, Zehr JP (2005) Vertical distributions of nitrogen-fixing phylotypes at Stn ALOHA in the oligotrophic North Pacific Ocean. Aquat Microb Ecol 38:3-14

Claquin P, Probert I, Lefebvre S, Veron B (2008) Effects of temperature on photosynthetic parameters and TEP production in eight species of marine microalgae. Aquat Microb Ecol 51:1-11

* Dron A, Rabouille S, Claquin P, Chang P, Raimbault V, Talec A, Sciandra A (2012a) Light-dark (12:12 h) quantification of carbohydrate fluxes in Crocosphaera watsonii. Aquat Microb Ecol 68:43-55

* Dron A, Rabouille S, Claquin P, Le Roy B, Talec A, Sciandra A (2012b) Light-dark (12:12) cycle of carbon and nitrogen metabolism in Crocosphaera watsonii WH8501: relation to the cell cycle. Environ Microbiol 14:967-981

* Dron A, Rabouille S, Claquin P, Talec A, Raimbault V, Sciandra A (2013) Photoperiod length paces the temporal orchestration of cell cycle and carbon-nitrogen metabolism in Crocosphaera watsonii. Environ Microbiol 15: 3292-3304

* Dubois M, Gilles KA, Hamilton JK, Rebers PA, Smith F (1956) Colorimetric method for determination of sugars and related substances. Anal Chem 28:350-356

K Engel A, Passow U (2001) Carbon and nitrogen content of transparent exopolymer particles (TEP) in relation to their Alcian Blue adsorption. Mar Ecol Prog Ser 219: $1-10$

Engel A, Thoms S, Riebesell U, Rochelle-Newall E, Zondervan I (2004) Polysaccharide aggregation as a potential sink of marine dissolved organic carbon. Nature 428:929-932

Flemming HC, Wingender J (2001) Relevance of microbial extracellular polymeric substances (EPSs) - Part I: Structural and ecological aspects. Water Sci Technol 43:1-8

* Garcia C, Prieto L, Echevarria F, Garcia-Lafuente J, Ruiz J, Rubin J (2002) Hydrodynamics and the spatial distribution of plankton and TEP in the Gulf of Cadiz (SW Iberian Peninsula). J Plankton Res 24:817-833

Glibert PM, Bronk DA (1994) Release of dissolved organic nitrogen by marine diazotrophic cyanobacteria, Trichodesmium spp. Appl Environ Microbiol 60:3996-4000

*Hewson I, Moisander PH, Morrison AE, Zehr JP (2007) Diazotrophic bacterioplankton in a coral reef lagoon: phylogeny, diel nitrogenase expression and response to phosphate enrichment. ISME J 1:78-91

Hong Y, Smith WO, White AM (1997) Studies on transparent exopolymer particles (TEP) produced in the Ross Sea (Antarctica) and by Phaeocystis antarctica (Prymnesiophyceae). J Phycol 33:368-376 
Karl D, Letelier R, Tupas L, Dore J, Christian J, Hebel D (1997) The role of nitrogen fixation in biogeochemical cycling in the subtropical North Pacific Ocean. Nature 388:533-538

Kiorbøe T (2000) Colonization of marine snow aggregates by invertebrate zooplankton abundance, scaling and possible role. Limnol Oceanogr 45:479-484

Klein C, Claquin P, Pannard A, Napoléon C, Le Roy B, Véron B (2011) Dynamics of soluble extracellular polymeric substances and transparent exopolymer particle pools in coastal ecosystems. Mar Ecol Prog Ser 427:13-27

K Letelier RM, Karl DM (1996) Role of Trichodesmium spp. in the productivity of the subtropical North Pacific Ocean. Mar Ecol Prog Ser 133:263-273

Levene $H$ (1960) Robust tests for equality of variances. In: Olkin I, Ghurye SG, Hoeffding W, Madow WG, Mann HB (eds) Contributions to probability and statistics: essays in honor of Harold Hotelling. Stanford University Press, Stanford, CA, p 278-292

* Mague TH, Friberg E, Hughes DJ, Morris I (1980) Extracellular release of carbon by marine phytoplankton - a physiological approach. Limnol Oceanogr 25:262-279

*Mari X, Burd A (1998) Seasonal size spectra of transparent exopolymeric particles (TEP) in a coastal sea and comparison with those predicted using coagulation theory. Mar Ecol Prog Ser 163:63-76

Mari X, Beauvais S, Lemee R, Pedrotti ML (2001) Non-Redfield $\mathrm{C}$ : $\mathrm{N}$ ratio of transparent exopolymeric particles in the northwestern Mediterranean Sea. Limnol Oceanogr 46:1831-1836

Mohr W, Intermaggio MP, LaRoche J (2010) Diel rhythm of nitrogen and carbon metabolism in the unicellular, diazotrophic cyanobacterium Crocosphaera watsonii WH8501. Environ Microbiol 12:412-421

Moisander PH, Beinart RA, Hewson I, White AE and others (2010) Unicellular cyanobacterial distributions broaden the oceanic N-2 fixation domain. Science 327: 1512-1514

Monod J (1942) Recherches sur la croissance des cultures bacteriennes. Hermann \& Cie, Paris

Monteiro FM, Follows MJ, Dutkiewicz S (2010) Distribution of diverse nitrogen fixers in the global ocean. Global Biogeochem Cycles 24, GB3017

*Montoya JP, Holl CM, Zehr JP, Hansen A, Villareal TA, Capone DG (2004) High rates of $\mathrm{N}_{2}$ fixation by unicellular diazotrophs in the oligotrophic Pacific Ocean. Nature 430:1027-1032

Morán XAG, Gasol JM, Arin L, Estrada M (1999) A comparison between glass fiber and membrane filters for the estimation of phytoplankton POC and DOC production. Mar Ecol Prog Ser 187:31-41

Mortain-Bertrand A, Descolas-Gros C, Jupin H (1988) Growth, photosynthesis and carbon metabolism in the temperate marine diatom Skeletonema costatum adapted to low temperature and low photon flux density. Mar Biol 100: 135-141

Mulholland MR, Bernhardt PW (2005) The effect of growth rate, phosphorus concentration, and temperature on $\mathrm{N}_{2}$ fixation, carbon fixation, and nitrogen release in continuous cultures of Trichodesmium IMS101. Limnol Oceanogr 50:839-849

Otero A, Vincenzini M (2004) Nostoc (Cyanophyceae) goes nude: extracellular polysaccharides serve as a sink for reducing power under unbalanced $\mathrm{C} / \mathrm{N}$ metabolism. J Phycol 40:74-81
Pakulski JD, Benner R (1992) An improved method for the hydrolysis and MBTH analysis of dissolved and particulate carbohydrates in seawater. Mar Chem 40:143-160

*Passow U (2000) Formation of transparent exopolymer particles, TEP, from dissolved precursor material. Mar Ecol Prog Ser 192:1-11

*Passow U (2002a) Production of transparent exopolymer particles (TEP) by phyto- and bacterioplankton. Mar Ecol Prog Ser 236:1-12

*Passow U (2002b) Transparent exopolymer particles (TEP) in aquatic environments. Prog Oceanogr 55:287-333

* Passow U, Alldredge AL (1995) A dye-binding assay for the spectrophotometric measurement of transparent exopolymer particles (TEP). Limnol Oceanogr 40:1326-1335

* Passow U, Alldredge AL, Logan BE (1994) The role of particulate carbohydrate exudates in the flocculation of diatom blooms. Deep Sea Res I 41:335-357

*Passow U, Shipe RF, Murray A, Pak DK, Brzezinski MA, Alldredge AL (2001) The origin of transparent exopolymer particles (TEP) and their role in the sedimentation of particulate matter. Cont Shelf Res 21:327-346

* Pedrotti ML, Peters F, Beauvais S, Vidal M, Egge J, Jacobsen A, Marrasé C (2010) Effects of nutrients and turbulence on the production of transparent exopolymer particles: a mesocosm study. Mar Ecol Prog Ser 419:57-69

* Penna A, Berluti S, Penna N, Magnani M (1999) Influence of nutrient ratios on the in vitro extracellular polysaccharide production by marine diatoms from the Adriatic Sea. J Plankton Res 21:1681-1690

* Rabouille S, Claquin P (2016) Photosystem-II shutdown evolved with nitrogen fixation in the unicellular diazotroph Crocosphaera watsonii. Environ Microbiol 18: 477-485

* Rabouille S, Salençon MJ (2005) Functional analysis of Microcystis vertical migration: a dynamic model as a prospecting tool. II. Influence of mixing, thermal stratification and colony diameter on biomass production. Aquat Microb Ecol 39:281-292

Rabouille S, Salençon MJ, Thebault JM (2005) Functional analysis of Microcystis vertical migration: a dynamic model as a prospecting tool: I - Processes analysis. Ecol Modell 188:386-403

Rabouille S, Staal M, Stal LJ, Soetaert K (2006) Modeling the dynamic regulation of nitrogen fixation in the cyanobacterium Trichodesmium sp. Appl Environ Microbiol 72: 3217-3227

Redfield AC (1934) On the proportions of organic derivatives in sea water and their relation to the composition of plankton. In: Daniel RJ (ed) James Johnstone Memorial Volume. University Press of Liverpool, p 176-192

Redfield AC, Ketchum BH, Richards FA (1963) The influence of organisms on the composition of sea-water. In: Hill MN (ed) The composition of seawater comparative and descriptive oceanography the sea: ideas and observations on progress in the study of the seas. Vol 2. WileyInterscience, New York, NY, p 26-77

Sambrotto RN, Savidge G, Robinson C, Boyd P and others (1993) Elevated consumption of carbon relative to nitrogen in the surface ocean. Nature 363:248-250

* Schneegurt MA, Sherman DM, Nayar S, Sherman LA (1994) Oscillating behavior of carbohydrate granule formation and dinitrogen fixation in the cyanobacterium Cyanothece sp. strain ATCC 51142. J Bacteriol 176:1586-1597

* Shi T, Ilikchyan I, Rabouille S, Zehr JP (2010) Genome-wide analysis of diel gene expression in the unicellular $\mathrm{N}_{2}$ - 
fixing cyanobacterium Crocosphaera watsonii WH 8501. ISME J 4:621-632

Sohm JA, Edwards BR, Wilson BG, Webb EA (2011) Constitutive extracellular polysaccharide (EPS) production by specific isolates of Crocosphaera watsonii. Front Microbiol 2:229

Stal LJ (2009) Is the distribution of nitrogen-fixing cyanobacteria in the oceans related to temperature? Environ Microbiol 11:1632-1645

Underwood GJC, Paterson DM, Parkes RJ (1995) The measurement of microbial carbohydrate exopolymers from intertidal sediments. Limnol Oceanogr 40: 1243-1253

Waite AM, Olson RJ, Dan HG, Passow U (1995) Sugarcontaining compounds on the cell surfaces of marine diatoms measured using concanavalin A and flow cytometry. J Phycol 31:925-933

Waterbury JB, Rippka R (1989) The order Chroococcales. In: Krieg NR, Holt JB (ed) Bergey's manual of systematic bacteriology. Williams \& Wilkins, Baltimore, MD, p 1728-1746

Waterbury JB, Watson SW, Valois FW (1988) Temporal separation of photosynthesis and dinitrogen fixation in the marine unicellular cyanobacterium Erythrosphaera marina. Eos 69:1089

Editorial responsibility: Ronald Kiene, Mobile, Alabama, USA
Webb EA, Ehrenreich IM, Brown SL, Valois FW, Waterbury JB (2009) Phenotypic and genotypic characterization of multiple strains of the diazotrophic cyanobacterium, Crocosphaera watsonii, isolated from the open ocean. Environ Microbiol 11:338-348

Wotton RS (2004) The ubiquity and many roles of exopolymers (EPS) in aquatic systems. Sci Mar 68:13-21

* Zehr JP, Carpenter EJ, Villareal TA (2000) New perspectives on nitrogen-fixing microorganisms in tropical and subtropical oceans. Trends Microbiol 8:68-73

Zehr JP, Waterbury JB, Turner PJ, Montoya JP and others (2001) Unicellular cyanobacteria fix $\mathrm{N}_{2}$ in the subtropical North Pacific Ocean. Nature 412:635-638

Kehr JP, Montoya JP, Hewson I, Mondragon E and others (2007) Nitrogenase gene expression and $\mathrm{N}_{2}$ fixation in the North Pacific Subtropical Gyre. Limnol Oceanogr 52: 169-183

Zhou J, Mopper K, Passow U (1998) The role of surface-active carbohydrates in the formation of transparent exopolymer particles by bubble adsorption of seawater. Limnol Oceanogr 43:1860-1871

* Zlotnik I, Dubinski Z (1989) The effect of light and temperature on DOC excretion by phytoplankton. Limnol Oceanogr 34:831-839

Submitted: May 9, 2016; Accepted: February 9, 2017

Proofs received from author(s): April 10, 2017 